\title{
Cloned Ribosomal Ribonucleic Acid Genes from Pseudomonas aeruginosa as Probes for Conserved Deoxyribonucleic Acid Sequences
}

\author{
KARL HEINZ SCHLEIFER,* WOLFGANG LUDWIG, JOSEF KRAUS, AND HERBERT FESTL \\ Lehrstuhl für Mikrobiologie, Technische Universität München, D-8000 Munich 2, Federal Republic of Germany
}

\begin{abstract}
Ribosomal ribonucleic acid (rRNA) genes were isolated from a PstI digest of Pseudomonas aeruginosa chromosomal deoxyribonucleic acid (DNA), cloned in Escherichia coli, and used as probes for conserved gene sequences. Recombinant plasmid pHF1 contained an 8,800-base pair insertion containing 5S, $16 \mathrm{~S}$, and $23 \mathrm{~S}$ rRNA genes. We constructed subclones of pHF1 containing parts of the 16S and 23S rRNA genes (pHF1.1) and parts of the 23S and 5S rRNA genes (pHF1.2). DNA-DNA hybridization experiments in which we used filter-bound chromosomal DNA from various bacteria and ${ }^{35}$ S-labeled plasmid rRNA genes (rDNA) indicated that the homology values reflected the actual phylogenetic distances to $P$. aeruginosa. Compared with oligonucleotide sequence analysis of 16S rRNA, a good correlation was found between DNA-rDNA homology values and $S_{A B}$ (similarity coefficient of $16 \mathrm{~S}$ rRNAs) values above 0.4 . The use of rDNA instead of rRNA in hybridization experiments offers several advantages; e.g., rDNA can easily be labeled in vitro, and the degree of relatedness can be expressed in terms of percent homolgy and does not have to be determined by laborious measurement of thermal stability, as in the case of rRNA.
\end{abstract}

Deoxyribonucleic acid (DNA)-DNA hybridization is a powerful tool for elucidation of close relationships among bacteria. However, it fails above the intrageneric level. Lower levels of relationships can be detected by comparing the primary structures of ribosomal ribonucleic acids (rRNA) either by sequencing or by hybridization. Comparative sequence analysis of $16 \mathrm{~S}$ rRNA has proved to be the best approach to determine lower levels of relationships (20). Moreover, this approach requires the use of specialized techniques which are not readily applicable to large numbers of strains. Determination of rRNA cistron similarities by hybridization is certainly not as accurate as the sequencing approach, but it is a simpler and more rapid technique. The similarities of rRNAs have usually been measured by the differences between the thermal stabilities of the homologous and heterologous DNA-rRNA duplexes (2). The percentage of rRNA homology to DNA is not a reliable measure of rRNA homology, because the amount of rRNA bound does not depend only on the actual rRNA homology (3). Therefore, it is not possible to express the degree of relatedness in terms of percent homology, and one has to use the more laborious measurement of thermal stability. The similarities of rRNAs have also been measured by adding competitor rRNA to the homologous hybridization reaction (15). By using this method, it is possible to determine competition homology values and to avoid determination of the thermal stability of the hybrids. The disadvantage of the latter method are the large amounts of unlabeled rRNA that are needed from the competitor strain. However, isolation of pure rRNA is one of the major difficulties of the DNA-rRNA hybridization method (16). Therefore, we decided to clone rRNA cistrons and to use the rRNA genes (rDNA) as a probe for studying distant phylogenetic relationships.

\footnotetext{
* Corresponding author.
}

\section{MATERIALS AND METHODS}

Organisms and growth conditions. Most of the strains which we used are listed in Table 1; also used were Escherichia coli RR28 and vector pHE3, which were received as gifts from $H$. Hennecke (ETH, Zürich, Switzerland).

Pseudomonads and $E$. coli were cultivated aerobically in

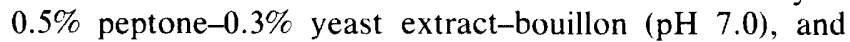
staphylococci, micrococci, and bacilli were cultivated in $1 \%$ peptone- $0.5 \%$ yeast extract $-0.5 \%$ glucose $-0.8 \%$ sodium chloride-bouillon ( $\mathrm{pH}$ 7.2). Streptococci were grown without aeration in CASO bouillon (E. Merck AG, Darmstadt, Federal Republic of Germany). The incubation temperature was $30^{\circ} \mathrm{C}$ for pseudomonads and micrococci and $35^{\circ} \mathrm{C}$ for streptococci, staphylococci, bacilli, and $E$. coli. Cells were harvested in the late logarithmic growth phase.

Isolation of rRNA and DNA. rRNAs were isolated and purified as described elsewhere (18). Extraction of chromosomal DNA was carried out by using the method of Marmur (12), with the modifications described by Meyer and Schleifer $(13,14)$. Plasmid DNA was isolated by the method of Clewell and Helinski (1) or by the rapid preparation procedure described by Klein et al. (11).

Labeling of rRNA and DNA. The rRNAs were partially hydrolyzed by mild alkali treatment in $500 \mathrm{mM}$ sodium borate buffer ( $\mathrm{pH} \mathrm{9.0)}$ at $70^{\circ} \mathrm{C}$ for $35 \mathrm{~min}$, using the method of Engel and Davidson (5). The resulting fragments were 5 -labeled by using $\left[\gamma^{32} \mathrm{P}\right]$ adenosine triphosphate (New England Nuclear Corp., Dreieich, Federal Republic of Germany) and T4 polynucleotide kinase (Bethesda Research Laboratories, Neu Isenburg, Federal Republic of Germany). The conditions used were those described by Stackebrandt et al. $(18,19)$. Excess $\left[\gamma^{32} \mathrm{P}\right]$ adenosine triphosphate was removed by thin-layer chromatography on diethylaminoethyl-cellulose glass plates (Macherey and Nagel, Düren, Federal Republic of Germany) which were developed with $0.45 \mathrm{M}$ ammonium formate- $0.1 \mathrm{M}$ ethylenediaminetetraacetate in $9 \mathrm{M}$ urea at $60^{\circ} \mathrm{C}$. 
Plasmid DNA and chromosomal DNA were labeled by nick translation, using $\left[\alpha-{ }^{35}\right.$ S $]$ thiodeoxyadenosine triphosphate (New England Nuclear Corp.) and a reaction kit from Bethesda Research Laboratories. The conditions used were those recommended by the manufacturer. The labeled DNA was separated from free $\left[\alpha^{-35}\right.$ S $]$ thiodeoxyadenosine triphosphate by filtration through Elutip (Schleicher \& Schuell, Dassel, Federal Republic of Germany).

Molecular cloning of rDNA. Chromosomal DNA from Pseudomonas aeruginosa was digested with restriction enzyme PstI (Bethesda Research Laboratories). The resulting fragments were analyzed by Southern hybridization (17) to ${ }^{32} \mathrm{P}$-labeled homologous $5 \mathrm{~S}, 16 \mathrm{~S}$, and $23 \mathrm{~S}$ rRNAs. Fragments which hybridized to all three rRNAs were recovered after agarose gel electrophoresis $[0.7 \%$ agarose in $40 \mathrm{mM}$ tris(hydroxymethyl)aminomethane-1 mM ethylenediaminetetraacetate- $5 \mathrm{mM}$ sodium acetate buffer, $\mathrm{pH} 8.3$ ] and ligated with PstI-digested $E$. coli vector pHE3 (8) by using T4 ligase (Bethesda Research Laboratories). After transformation of $E$. coli RR28, positive clones were detected by Southern hybridization of filter-bound plasmid DNA to ${ }^{32} \mathrm{P}$-labeled homologous $23 \mathrm{~S}$ rRNA. Subclones were constructed by ligation of digested (BamHI or BstEII or both) vector pHE3 with restriction fragments (BamHI or $B s t$ EII or both) of the initial recombinant plasmid.

Hybridization. Southern hybridizations of filter-bound restriction fragments to ${ }^{32} \mathrm{P}$-labeled rRNAs were carried out in $3 \times \mathrm{SSC}(0.45 \mathrm{M} \mathrm{NaCl}$ plus $0.045 \mathrm{M}$ sodium citrate, $\mathrm{pH} 7.0)$ containing $25 \%$ formamide at $50^{\circ} \mathrm{C}$ for $16 \mathrm{~h}$. Fixation of unlabeled DNA on nitrocellulose filters (Schleicher \& Schuell) was performed by the method of Gillespie and Spiegelman (7). DNA-rDNA hybridization experiments were performed in $3 \times$ SSC containing $25 \%$ formamide (optimal conditions) or $38.5 \%$ formamide (stringent conditions) at $60^{\circ} \mathrm{C}$ for 18 to $20 \mathrm{~h}(10)$

\section{RESULTS}

Cloning of rRNA genes. The Pst I digest of $P$. aeruginosa chromosomal DNA was fractionated on $0.7 \%$ agarose gels (Fig. 1). Southern hybridizations of the fragments were done to ${ }^{32}$ P-labeled $5 \mathrm{~S}, 16 \mathrm{~S}$, and $23 \mathrm{~S}$ homologous rRNAs. The autoradiograph in Fig. 1 shows multiple bands. Fragments of about 8,800 base pairs which hybridized to all three rRNAs were isolated and ligated with $P$ st I-digested $E$. coli vector pHE3. The recombinant vectors were amplified in $E$. coli RR28. Positive clones were detected by Southern hybridization of filter-bound plasmid DNA to homologous ${ }^{32} \mathrm{P}$-labeled $23 \mathrm{~S}$ rRNA. One of the recombinant plasmids, which was used in the studies described below, contained an 8,800-base pair insertion and was designated $\mathrm{pHF} 1$. This plasmid was characterized by restriction analysis (Fig. 2). The orientation of the rDNA was deduced by selective hybridization of ${ }^{32} \mathrm{P}$-labeled 5S, 16S, and 23S rRNAs to filter-bound BstEIIgenerated fragments of pHF1. Restriction fragments resulting from digestion of pHF1 by BstEII or by BstEII and $B a m H I$ were subcloned in vector $\mathrm{pHE}$. Purified subclone pHF1.1 contained a 2,200-base pair insertion which covered parts of the $16 \mathrm{~S}$ and $23 \mathrm{~S}$ rDNAs (Fig. 2), whereas subclone pHF1.2 contained a 1,700-base pair fragment which included the 5S rDNA and part of the 23S rDNA (Fig. 2). The presence of transfer ribonucleic acid genes was not tested in this assay.

Hybridization experiments. Various DNA-DNA hybridization experiments with rDNA and chromosomal DNAs were carried out by using the filter technique to show the usefulness of cloned rDNA for phylogenetic studies. ${ }^{35} \mathrm{~S}$-labeled cloned rDNA from $P$. aeruginosa was hybridized to filterbound chromosomal DNAs of organisms representing different phylogenetic distances (Table 1). The phylogenetic relationships of the organisms used had been elucidated previously by $16 \mathrm{~S}$ rRNA cataloging (21) and by DNA-rRNA cistron homology studies $(4,15)$. The pHE3 vector alone showed no homology with the chromosomal DNAs. This was demonstrated by hybridization experiments with ${ }^{35} \mathrm{~S}$ labeled pHE3 DNA and unlabeled insertion rDNA. Less than $1 \%$ of the radioactivity was bound to chromosomal DNAs, indicating that competition between vector DNA and rDNA did not occur. Table 1 summarizes the data obtained from various hybridization experiments. ${ }^{35} \mathrm{~S}$-labeled DNAs of plasmids pHF1, pHF1.1, and pHF1.2 were used, as well as labeled insertion rDNA containing parts of $16 \mathrm{~S}$ and $23 \mathrm{~S}$ rRNA genes. The latter rDNA was excised with Bst EII from plasmid pHF1.1. Both rDNA binding values and DNArDNA homology values are listed in Table 1. The homology values were determined by normalizing the percentage of radioactivity bound in the heterologous reaction to the percentage of radioactivity bound in the homologous re-

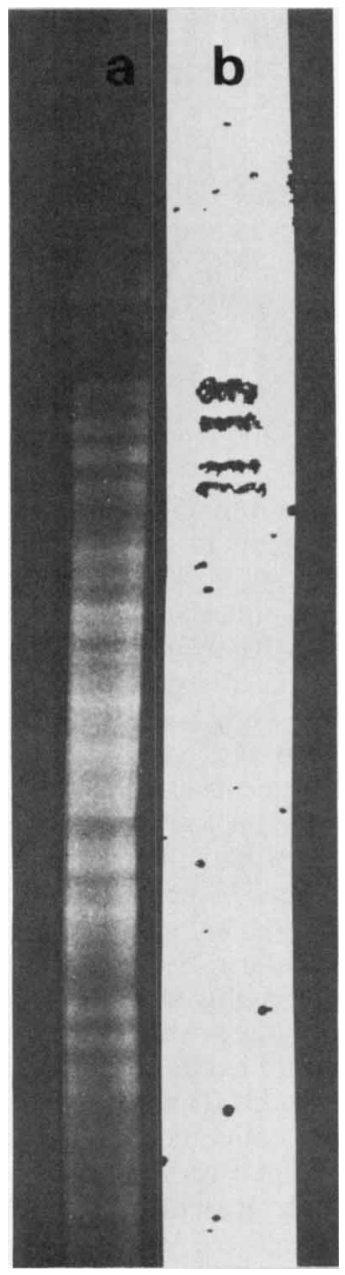

FIG. 1. Gel electrophoresis $(0.7 \%$ agarose) of $P$. aeruginosa DNA digested with restriction endonuclease Pst $\mathbf{I}$. Lane a was stained with ethidium bromide and visualized under ultraviolet light. Lane $b$ was a Southern transfer analysis in which $\left[\gamma^{-32} \mathrm{P}\right]$ adenosine triphosphate-labeled 23S rRNA from $P$. aeruginosa was used as the radioactive probe. Hybridization was carried out as described in the text. 

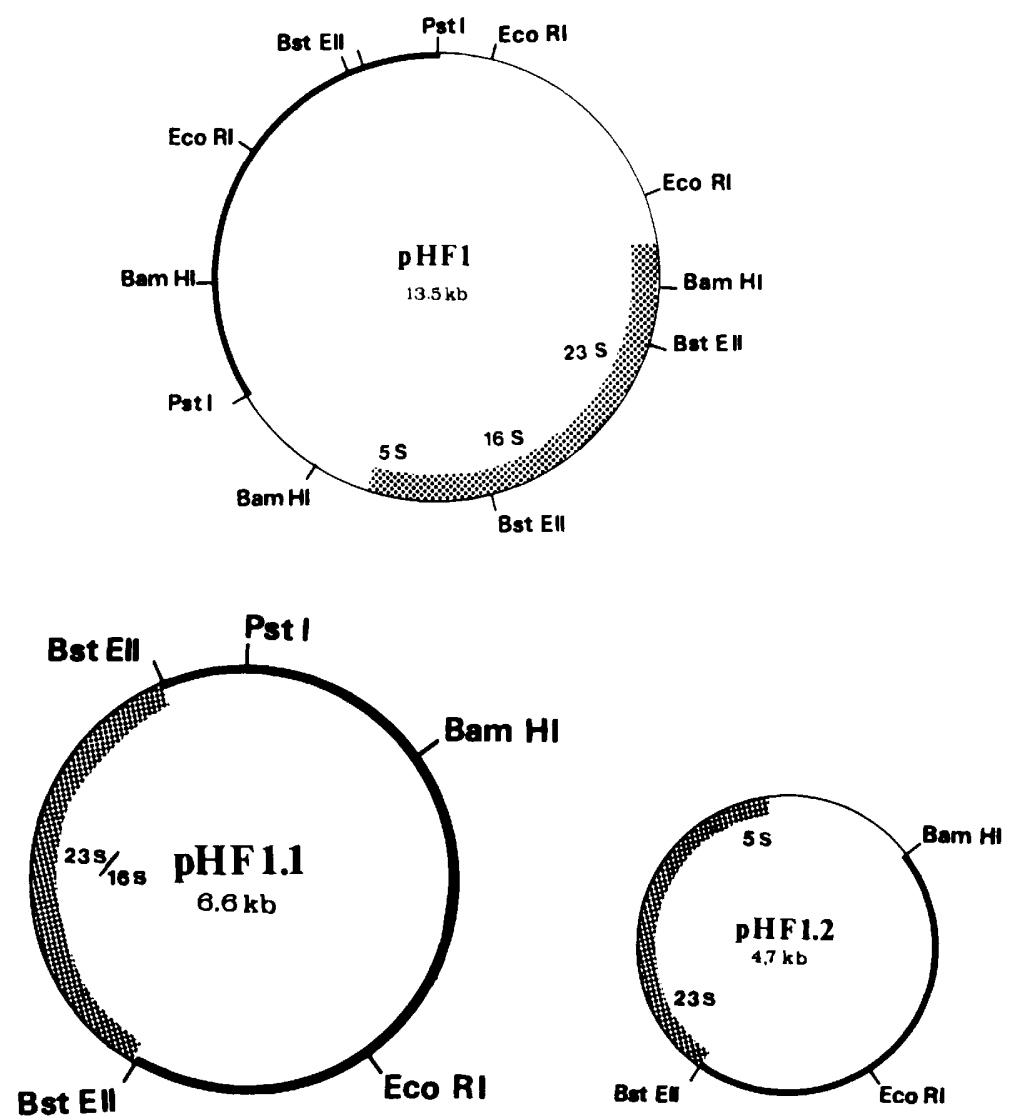

FIG. 2. Restriction endonuclease map of plasmids derived from $E$. coli vector $\mathrm{pH}$. The thick solid line indicates vector DNA. Plasmid $\mathrm{pHF} 1$ contains the coding region for $5 \mathrm{~S}, 23 \mathrm{~S}$, and $16 \mathrm{~S}$ rRNAs from $P$. aeruginosa. Plasmids $\mathrm{pHF} 1.1$ and $\mathrm{pHF} 1.2$ are derived from $\mathrm{pHF} 1$. The insertion of plasmid pHF1.1 consists of the 2.2-kilobase pair BstEII fragment of pHF1 containing parts of the 23S and 16S rRNA genes. The insertion of plasmid pHF1.2 consists of the 1.7-kilobase pair BamHI-BstEII fragment of pHF1 containing 5S rRNA genes and part of the 23S rRNA genes. $\mathrm{kb}$, kilobase.

action. Radioactively labeled probes of plasmid pHF1 were hybridized with filter-bound chromosomal DNA from various bacteria under optimal and stringent conditions. The DNA homology values of the closely related pseudomonads were similar in both experiments. However, the less related pseudomonads and the gram-positive bacteria showed significantly lower homology values under stringent conditions. Plasmids pHF1.2 and pHF1.1 and the insertion DNA were hybridized under optimal conditions with filter-bound chromosomal DNAs. pHF1.1, which contained parts of the $16 \mathrm{~S}$ and 23S rRNA genes, was more specific than pHF1.2, which contained 5S rRNA and parts of the $23 \mathrm{~S}$ rRNA. The border line of resolution seemed to be Pseudomonas cepacia, whereas in most cases Pseudomonas diminuta yielded homology values which were not significantly different from those of gram-positive bacteria. Separation of $P$. diminuta from gram-positive bacteria could be obtained only with plasmid pHF1.1 and its insertion rDNA.

Our data indicate that the homology values deduced from the levels of rDNA binding reflect actual phylogenetic relatedness. This is in contrast to DNA-rRNA hybridization studies, in which the thermal stability of the DNA-rRNA hybrids and not the level of rRNA binding is a reliable measure for determining relationships (Table 2).

A graphic representation of the DNA-rDNA homology values is shown in Fig. 3, where they are compared with the phylogenetic relationships deduced from 16S rRNA cataloging data (21).

\section{DISCUSSION}

The conserved character, the ubiquitous distribution, the functional constancy, and the genetic stability of rRNAs make them ideal markers to measure distant phylogenetic relationships $(6,16)$. The most useful method for determining phylogenetic relationships among bacteria is presently comparative sequence analysis of $16 \mathrm{~S}$ rRNAs. However, this is a rather sophisticated, expensive, and laborious technique which is not suitable for routine studies of large groups of strains. Determination of rRNA cistron similarity via hybridization is certainly less accurate and more restricted than the sequencing approach. The hybridization method is not useful for detecting deep branchings in the bacterial kingdom, but it can be used to determine phylogenetic relationships among related genera. Independent studies by Schleifer and Stackebrandt (6) and Johnson and Harich (9) have shown that the correlation between rRNA cistron similarity studies and 16S rRNA oligonucleotide analysis is very good for $\mathrm{S}_{\mathrm{AB}}$ (similarity coefficient of $16 \mathrm{~S}$ rRNAs) values above 0.45 .

DNA-rRNA hybridization studies are not as easily and as reliably performed as DNA-DNA hybridization studies. The main disadvantages have been discussed previously (16) (see above). Since DNA-DNA hybridization studies are easier to perform and also are more accurate than comparisons of rRNA hybrids, we cloned rRNA cistrons and used the cloned rDNA as a probe for conserved gene sequences. 
TABLE 1. DNA-rDNA homology values and levels of rDNA binding between filter-bound chromosomal DNAs from various bacteria and recombinant plasmids containing cloned rRNA genes from $P$. aeruginosa

\begin{tabular}{|c|c|c|c|c|c|}
\hline \multirow[b]{2}{*}{ Source of filter-bound chromosomal DNA ${ }^{a}$} & \multicolumn{5}{|c|}{$\%$ DNA-rDNA homology with ${ }^{35}$ S-labeled DNA from: ${ }^{b}$} \\
\hline & $\begin{array}{l}\text { pHF1 under } \\
\text { optimal } \\
\text { hybridization } \\
\text { conditions }{ }^{c}\end{array}$ & $\begin{array}{l}\text { pHF1 under } \\
\text { stringent } \\
\text { hybridization } \\
\text { conditions }\end{array}$ & $\begin{array}{l}\text { pHF1.2 under } \\
\text { optimal } \\
\text { hybridization } \\
\text { conditions }\end{array}$ & $\begin{array}{l}\text { pHFl.1 under } \\
\text { optimal } \\
\text { hybridization } \\
\text { conditions }\end{array}$ & $\begin{array}{l}\text { Inserted DNA of } \\
\text { pHFl.1 under } \\
\text { optimal } \\
\text { hybridization } \\
\text { conditions }\end{array}$ \\
\hline Pseudomonas aeruginosa DSM $50071^{\mathrm{T}}$ & $100(0.133)^{d}$ & $100(0.089)$ & $100(0.049)$ & $100(0.043)$ & $100(0.046)$ \\
\hline Pseudomonas putida DSM $291^{\mathrm{T}}$ & $97(0.13)$ & $98(0.087)$ & $100(0.049)$ & $95(0.041)$ & $95(0.044)$ \\
\hline Pseudomonas fluorescens DSM $50090^{\mathrm{T}}$ & $93(0.124)$ & $93(0.083)$ & $90(0.044)$ & $94(0.041)$ & $85(0.039)$ \\
\hline Pseudomonas alcaligenes DSM $50342^{\mathrm{T}}$ & $94(0.124)$ & $96(0.085)$ & $88(0.043)$ & $85(0.036)$ & $89(0.041)$ \\
\hline Pseudomonas maltophilia DSM $50170^{\mathrm{T}}$ & $63(0.082)$ & $52(0.046)$ & $67(0.033)$ & $57(0.024)$ & $69(0.032)$ \\
\hline Pseudomonas acidovorans DSM $50251^{\mathrm{T}}$ & $51(0.068)$ & $44(0.039)$ & $49(0.024)$ & $37(0.016)$ & $50(0.023)$ \\
\hline Pseudomonas cepacia DSM 50181 & $49(0.066)$ & $42(0.042)$ & $43(0.021)$ & $33(0.014)$ & $35(0.016)$ \\
\hline Pseudomonas diminuta DSM 1639 & $37(0.050)$ & $33(0.029)$ & $28(0.014)$ & $25(0.011)$ & $35(0.016)$ \\
\hline Streptococcus cremoris Kiel 4E9 & $34(0.045)$ & $28(0.025)$ & $29(0.014)$ & $15(0.006)$ & $20(0.009)$ \\
\hline Streptococcus rattus ATCC $19645^{\mathrm{T}}$ & $36(0.048)$ & $22(0.019)$ & $28(0.014)$ & $15(0.006)$ & $15(0.007)$ \\
\hline Streptococcus intermedius ATCC 27335 & $34(0.045)$ & & & & \\
\hline Staphylococcus epidermidis ATCC $14990^{\mathrm{T}}$ & $42(0.056)$ & $31(0.027)$ & & & \\
\hline Micrococcus luteus CCM $169^{\mathrm{T}}$ & $24(0.032)$ & $21(0.019)$ & $16(0.008)$ & $7(0.003)$ & $8(0.0037)$ \\
\hline Micrococcus varians CCM $884^{\mathrm{T}}$ & & & $15(0.008)$ & $8(0.0034)$ & $8(0.0037)$ \\
\hline Bacillus subtilis ATCC 6633 & $21(0.028)$ & & & & \\
\hline Bacillus cereus ATCC 14579 & $35(0.047)$ & & & & \\
\hline Bacillus megaterium CCM 2007 & $35(0.047)$ & & & & \\
\hline Bacillus brevis CCM 2050 & $31(0.041)$ & & & & \\
\hline
\end{tabular}

${ }^{a}$ ATCC, American Type Culture Collection, Rockville, Md.; CCM, Czechoslovak Culture Collection of Microorganisms, Brno, Czechoslovakia; DSM, Deutsche Sammlung von Mikroorganismen, Göttingen, Federal Republic of Germany; Kiel, Streptokokkenzentrale der Bundesanstalt für Milchforschung, Kiel, Federal Republic of Germany. T = type strain.

${ }^{b}$ The specific activities of the probes were as follows: pHF1, $600,000 \mathrm{cpm} / \mu \mathrm{g}$ of DNA; pHF1.1, $585,000 \mathrm{cpm} / \mu \mathrm{of} \mathrm{DNA} ; \mathrm{pHF} 1.2,445,000 \mathrm{cpm} / \mu \mathrm{g}$ of DNA; inserted DNA of pHF1.1, 500,000 $\mathrm{cpm} / \mu \mathrm{g}$ of DNA.

${ }^{c}$ Optimal hybridization conditions were $3 \times$ SSC containing $25 \%$ formamide at $60^{\circ} \mathrm{C}$; stringent hybridization conditions were $3 \times$ SSC containing $38.5 \%$ formamide at $60^{\circ} \mathrm{C}$.

${ }^{d}$ The values in parentheses are rDNA binding values (in micrograms of rDNA bound per $100 \mu \mathrm{g}$ of chromosomal DNA).

Radioactively labeled plasmids containing rDNA fragments from $P$. aeruginosa were used for hybridization experiments with filter-bound chromosomal DNAs from various bacteria. $P$. aeruginosa was chosen for this investigation because pseudomonads are the best-studied group of organisms with regard to comparative rRNA analyses $(4,15,21)$.

To establish the usefulness of the method, DNAs from bacteria belonging to different phylogenetic groups were used. The DNA-rDNA hybridization values resulted in a

TABLE 2. Comparison of DNA-rDNA and DNA-rRNA hybridization studies

\begin{tabular}{|c|c|c|c|}
\hline \multirow{2}{*}{$\begin{array}{l}\text { Source of filter- } \\
\text { bound DNA }\end{array}$} & \multicolumn{2}{|c|}{$\begin{array}{l}{ }^{14} \mathrm{C} \text {-labeled } 23 \mathrm{~S} \text { rRNA } \\
\text { from } P \text {. fluorescens }{ }^{\prime \prime}\end{array}$} & \multirow{2}{*}{$\begin{array}{c}\% \text { rDNA binding } \\
\text { with }{ }^{35} \text { S-labeled } \\
\text { rDNA from } \\
P . \text { aeruginosa }\end{array}$} \\
\hline & $\begin{array}{l}T_{m(e)} \\
\left({ }^{\circ} \mathrm{C}\right)^{b}\end{array}$ & $\begin{array}{c}\text { \% rRNA } \\
\text { binding }\end{array}$ & \\
\hline P. fluorescens & 81.0 & 0.14 & 0.124 \\
\hline$P$. aeruginosa & 76.5 & 0.12 & 0.133 \\
\hline$P$. putida & 77.5 & 0.16 & 0.130 \\
\hline$P$. alcaligenes & 76.5 & 0.11 & 0.124 \\
\hline P. maltophilia & 67.5 & 0.09 & 0.082 \\
\hline$P$. cepacia & 64.5 & 0.07 & 0.066 \\
\hline P. acidovorans & 61.0 & 0.07 & 0.068 \\
\hline$P$. diminuta & 61.0 & 0.05 & 0.050 \\
\hline B. megaterium & 56.0 & 0.11 & 0.047 \\
\hline B. subtilis & 56.0 & 0.10 & 0.028 \\
\hline
\end{tabular}

${ }^{a}$ Data from reference 4 .

${ }^{b} T_{m(e)}$, Temperature at which $50 \%$ of the bound rRNA or rDNA was eluted from the filters.

c Plasmid pHF1 was used as the source of rDNA. Hybridization was carried out under optimal conditions. dendrogram of relatedness very similar to the results obtained from competition (15) or thermal stability experiments (4). Compared with oligonucleotide cataloging of $16 \mathrm{~S}$ rRNA, a good correlation was found with $S_{A B}$ values above 0.4 (Fig. 3 ). One of the main advantages of the DNA-rDNA hybridization technique was that, at least with regard to the organisms studied, the measurement of DNA binding homology was sufficient to determine phylogenetic relationships (Tables 1 and 2).

DNA-rRNA hybridization experiments with labeled rRNA from Pseudomonas fluorescens showed that the rRNA binding values of bacilli and some nonrelated grampositive bacteria were of the same order as the rRNA binding values of homologous or closely related strains (4) (Table 2). This is in contrast to our results; we found that the binding of labeled rDNA to filter-bound chromosomal DNA reflects actual relatedness (Tables 1 and 2). Thus, the binding of filter-bound DNA of $P$. aeruginosa and $P$. fluorescens is high, whereas that of bacilli and nonrelated gram-positive bacteria is rather low. We cannot yet give an accurate explanation for the different behavior of rRNA and rDNA with regard to binding to heterologous DNA. A possible explanation is that there is more specific association of filter-bound DNA to rDNA than to rRNA. Moreover, rRNA is a single-stranded probe that can readily saturate filterbound complementary DNA, whereas the same is not possible with double-stranded rDNA probes. In the latter case, the homologous reaction of the complementary strands of rDNA in solution may compete with heterologous filterbound DNA and may suppress nonspecific binding.

As in DNA-rRNA hybridization studies, the boundary of resolution lies at $16 \mathrm{~S}$ rRNA ologonucleotide $S_{A B}$ values 

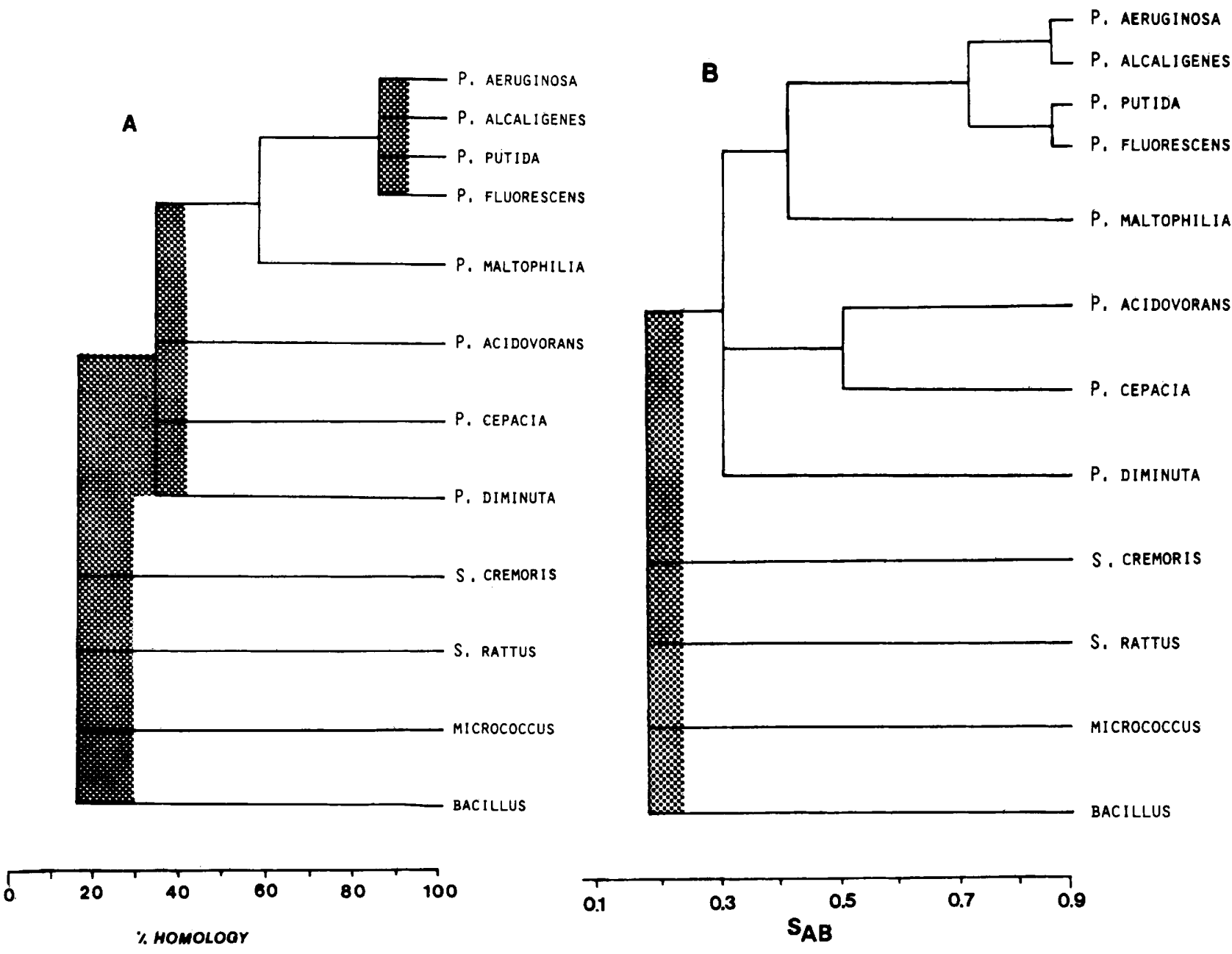

FIG. 3. Comparison of the DNA-rDNA homology values obtained with cloned rDNA from $P$. aeruginosa (A) and the $\mathrm{S}_{\mathrm{AB}}$ values deduced from 16S rRNA oligonucleotide analyses (B) (21). The stippled areas indicate approximate branching points.

above about 0.4 (Fig. 3). Thus, cloning of rRNAs from a limited number of eubacteria would be sufficient to use them as probes for the major lines of descent. Further studies are planned to check whether the results obtained with cloned rDNA of $P$. aeruginosa can be confirmed with cloned rDNAs of other bacteria. Experiments with cloned rDNAs of Bacillus subtilis and Micrococcus luteus are in progress.

The use of rDNA instead of rRNA also offers additional advantages. rRNA is usually labeled in vivo, whereas DNA can also be easily labeled in vitro by the nick-translation method. The cloned rDNA fragments can be reduced in size, and fragments of different conserved characters can be isolated and recloned.These fragments may be used as probes for détermining even lower degrees of phylogenetic relatedness within procaryotes.

\section{ACKNOWLEDGMENTS}

This work was supported by a grant from the Deutsche Forschungsgemeinschaft and by the Fonds der Chemischen Industrie.

We thank R. Kilpper-Bälz and W. Staudenbauer for helpful discussions and $\mathrm{H}$. Huber for typing the manuscript.

\section{LITERATURE CITED}

1. Clewell, D. B., and D. R. Helinski. 1969. Supercoiled DNA protein complex in Escherichia coli: purification and induced conversion to an open circular DNA form. Proc. Natl. Acad. Sci. U.S.A. 62:1159-1166.

2. De Ley, J., and J. De Smedt. 1975. Improvements of the membrane filter method for DNA-rRNA hybridization. Antonie van Leeuwenhoek J. Microbiol. Serol. 41:287-307.

3. De Smedt, J., and J. De Ley. 1977. Intra- and intergeneric similarities of Agrobacterium ribosomal ribonucleic acid cistrons. Int. J. Syst. Bacteriol. 27:222-240.

4. De Vos, P., and J. De Ley. 1983. Intra- and intergeneric similarities of Pseudomonas and Xanthomonas ribosomal ribonucleic acid cistrons. Int. J. Syst. Bacteriol. 33:487-509.

5. Engel, J. D., and N. Davidson. 1978. Addition of polyadenylic acid to RNA using polynucleotide phosphorylase: an improved method for electron microscopic visualization of RNA-DNA hybrids. Biochemistry 17:3883-3888.

6. Fox, G. E., E. Stackebrandt, R. B. Hespell, J. Gibson, J. Maniloff, T. A. Dyer, R. S. Wolfe, W. E. Balch, R. S. Tanner, L. J. Magrum, L. B. Zablen, R. Blakemore, R. Gupta, L. Bonen, B. J. Lewis, D. A. Stahl, K. R. Luehrsen, K. N. Chen, and C. R. Woese. 1980. The phylogeny of prokaryotes. Science 209: $457-463$.

7. Gillespie, D., and S. Spiegelman. 1965. A quantitative assay for DNA-RNA hybrids with DNA immobilized on a membrane. J. Mol. Biol. 12:829-842.

8. Hennecke, H., I. Günther, and F. Binder. 1982. A novel cloning vector for the direct selection of recombinant DNA in $E$. coli. Gene 19:231-234.

9. Johnson, J. L., and B. Harich. 1983. Comparisons of procedures 
for determining ribosomal ribonucleic acid similarities. Curr. Microbiol. 9:111-120.

10. Kilpper, R., U. Buhl, and K. H. Schleifer. 1980. Nucleic acid homology studies between Peptococcus saccharolyticus and various anaerobic and facultative anaerobic gram-positive cocci. FEMS Microbiol. Lett. 8:205-210.

11. Klein, R. D., E. Selsing, and R. D. Wells. 1980. A rapid microscale technique for isolation of recombinant plasmid DNA suitable for restriction enzyme analysis. Plasmid 3:88-91.

12. Marmur, J. 1961. A procedure for the isolation of deoxyribonucleic acids from microorganisms. J. Mol. Biol. 3:208-218.

13. Meyer, S. A., and K. H. Schleifer. 1975. Rapid procedure for the approximate determination of the deoxyribonucleic acid base composition of micrococci, staphylococci, and other bacteria. Int. J. Syst. Bacteriol. 25:383-385.

14. Meyer, S. A., and K. H. Schleifer. 1978. Deoxyribonucleic acid reassociation in the classification of coagulase-positive staphylococci. Arch. Microbiol. 117:183-188.

15. Palleroni, N. J., R. Kunisawa, R. Contopoulou, and $\mathbf{M}$. Doudoroff. 1973. Nucleic acid homologies in the genus Pseudomonas. Int. J. Syst. Bacteriol. 23:333-339.
16. Schleifer, K. H., and E. Stackebrandt. 1983. Molecular systematics of prokaryotes. Annu. Rev. Microbiol. 37:143-187.

17. Southern, E. M. 1975 . Detection of specific sequences among DNA fragments separated by gel electrophoresis. J. Mol. Biol. 98:503-517.

18. Stackebrandt, E., W. Ludwig, K. H. Schleifer, and H. J. Gross. 1981. Rapid cataloguing of ribonuclease T1 resistant oligonucleotides from ribosomal RNAs for phylogenetic studies. J. Mol. Evol. 17:227-236.

19. Stackebrandt, E., E. Seewaldt, W. Ludwig, K. H. Schleifer, and B. A. Huser. 1982. Classification of Methanothrix soehngenii elucidated by a modified technique of sequencing oligonucleotides from 16S rRNA. Zentralbl. Bakteriol. Parasitenkd. Infektionskr. Hyg. Abt. 1 Orig. Reihe C 3:90-100.

20. Stackebrandt, E., and C. R. Woese. 1981. The evolution of prokaryotes, p. 1-31. In M. I. Carlile, I. F. Collins, B. E. B. Moseley (ed.), Molecular and cellular aspects of microbial evolution. Cambridge University Press, Cambridge.

21. Woese, C. R., P. Blanz, and C. M. Hahn. 1984. What isn't a pseudomonad: the importance of nomenclature in bacterial classification. Syst. Appl. Microbiol. 5:179-195. 